\title{
РЕЗУЛЬТАТИ ЕКСПЕРИМЕНТАЛЬНОЇ ПІДГОТОВКИ МАЙБУТНІХ ФАХІВЦІВ ІЗ ФІЗИЧНОЇ КУЛЬТУРИ І СПОРТУ ДО ВПРОВАДЖЕННЯ ЦИФРОВИХ ТЕХНОЛОГІЙ У ПРОФЕСІЙНІЙ ДІЯЛЬНОСТІ
}

\begin{abstract}
У статті акцентовано на результатах експерименту щодо підготовки майбутніх фахівиів із ФКіС до впровадження цииррових технологій у професійній діяльності. Лише володіючи достатнім рівнем технологічної підготовленості, інформаційної компетентності, цифрової грамотності фахівець із ФКіС здатний орієнтуватися в проблемних ситуаціях, знаходити раціональні способи розв'язання професійних проблем $і$ бути конкурентоспроможним на ринку праці, щчо приводить до дедалі ширшого використання IT в освітньому процесі майбутніх фахівиів. Під час експериментальної підготовки майбутніх фахівців із ФКіС до впровадження циифрових технологій у професійній діяльності було доцільно поєднані традиційні методи навчання та інноваційні технологї̈, щчо передбачають використання інновацій не лище в навчально-виховному прочесі, а й для професійного зростання та фізичного вдосконалення; широко використано новітні форми організації та проведення навчальних занять зі зростанням ролі інтерактивних форм організації навчального проиесу, використанням індивідуалізованих освітніх траєкторій для студентів; залучено сучасні технології і засоби контролю; створено комплекси інноваційних гімнастичних вправ та відповідний ичфровий супровід. Проведення експериментальної підготовки майбутніх фахівиів із ФКіС до впровадження ичиррових технологій у професійній діяльності вимагало проведення педагогічного експерименту, який передбачав порівняння навчальних досягнень майбутніх фахівців із ФКіС контрольної та експериментальної груп. Було розроблено, відповідно, три критерії- предметний, практичний і психологічний. Їхніми показниками виступили обсяг знань, інформативна підготовленість, організаційні дії, мотивація, самоаналіз. Педагогічний експеримент показав ефективність запропонованої експериментальної підготовки майбутнього фахівия із ФКіС до впровадження ичифрових технологій у професійній діяльності, шуо підтверджено статистичними методами (методи Ст'юдента) на рівні значущзості 0,05.
\end{abstract}

Ключові слова: професійна підготовка, студенти факультетів фізичної культури і спорту, експеримент, критерії, рівні, цицррові технології.

\section{Serhii LAZORENKO, orcid.org/0000-0001-6493-8514 Candidate of Sciences in Physical Education and Sports, Associate Professor, Head of the Department of Sports Disciplines and Physical Education Sumy State Pedagogical University named after A. S. Makarenko} (Sumy,Ukraine)shiinna@ukr.net

\section{RESULTS OF EXPERIMENTAL TRAINING OF FUTURE SPECIALISTS IN PHYSICAL CULTURE AND SPORTS FOR THE INTRODUCTION OF DIGITAL TECHNOLOGIES IN PROFESSIONAL ACTIVITY}

The article focuses on the results of the experiment on the training of future specialists FC\&S for the introduction of digital technologies in professional activities. Only with a sufficient level of technological training, information competence, digital literacy, a specialist with FC\&S is able to navigate in problem situations, find rational ways to solve professional problems and be competitive in the labor market, which leads to increasing use of IT in the educational process of future professionals. During the experimental training of future FC\&S specialists for the introduction of digital technologies in professional activities, it was expedient to combine traditional teaching methods and innovative technologies that involve the use of innovations not only in the educational process, but also for professional growth and physical improvement; the latest forms of organization and conduct of educational classes are widely used with the growing role of interactive forms of organization of the educational process, the use of individualized educational trajectories for students; modern technologies and means of control are involved; complexes of innovative gymnastic exercises and the corresponding digital support are created. Conducting experimental training of future $F C \& S$ specialists for the introduction of digital technologies in professional activities required a pedagogical experiment, which involved 
comparing the educational achievements of future FC\&S specialists of the control and experimental groups. Three criteria were developed respectively - subject, practical and psychological. Their indicators were the amount of knowledge, IT training, organizational actions, motivation, introspection. The pedagogical experiment showed the effectiveness of the proposed experimental training of the future specialist of FC\&S for the introduction of digital technologies in professional activities, which is confirmed by statistical methods (Student's methods) at a significance level of 0.05 .

Key words: professional training, students of the faculties of physical culture and sports, experiment; criteria, levels, digital technologies.

Постановка проблеми. Новітні тенденції соціуму вимагають розвитку системи освіти та підготовки майбутніх фахівців фізичної культури та спорту (далі - ФКіС) на засадах цифрових технологій, створенні та функціонуванні належного високотехнологічного та високоякісного інформаційно-освітнього середовища. Його значення останнім часом зростає і якісно впливає на процес формування та розвитку інформаційно-цифрової культури майбутніх фахівців із ФКіС. Лише володіючи достатнім рівнем технологічної підготовленості, інформаційної компетентності, цифрової грамотності фахівець із ФКіС здатний орієнтуватися в проблемних ситуаціях, знаходити раціональні способи розв'язання професійних проблем i бути конкурентоспроможним на ринку праці, що приводить до ширшого використання IT в освітньому процесі майбутніх фахівців.

Це зумовлює потребу в суттєвих змінах у професійній підготовці майбутніх фахівців із ФКіС, вимагає постійного підвищення їхнього професійного рівня. На ЗВО покладається відповідальність за підготовку фахівців, зміст і рівень кваліфікації яких адекватні інноваціям, що відбуваються в галузі фізичної культури і спорту. Тому винятково важливого значення набуває модернізація професійної підготовки фахівців фізичної культури у ЗВО у напрямі опанування студентами комплексу знань, умінь і навичок у галузі цифрових технологій, формування професійних інтересів, професійних мотивів та ціннісних орієнтацій, що мобілізують на створення інновацій, їх освоєння й використання у професійній діяльності.

Аналіз досліджень. Одним зі знакових напрямів розвитку інформаційно-цифрової компетентності майбутніх фахівців із ФКіС, який відображає зміни суспільства і співзвучний із бурхливим розвитком науково-технічного забезпечення, $\epsilon$ інформатизація освіти. На переконання Р. Гуревича (Гуревич, Коломієць, 2010), одним із найважливіших завдань ЗВО варто вважати озброєння студентів знаннями й навичками використання ЦТ. Фахівці вказують на істотні переваги використання ЦТ у навчанні, порівняно 3 традиційними заняттями, серед яких - розширення можливості представлення інформації, підвищення мотивації студентів за рахунок новизни роботи
3 комп'ютером, якісної зміни контролю діяльності студентів, доступ до широкого кола інформації тощо (Гуревич, Коломієць, 2010). Ми погоджуємося з О. Сухобоком (Сухобок, 2011), який вважає IT засобом активізації самостійної роботи майбутніх фахівців із ФКіС. В. Ашанін (Ашанін, 2017) переконливо доводить існування попиту на фахівців 3 інформаційного забезпечення фізичного виховання й спорту. Науковці вказують на важливість проблеми пошуку шляхів модернізації процесу професійної підготовки майбутніх фахівців фізичної культури та спорту відповідно до сучасних тенденцій розвитку галузі ФКіС, важливість дослідження механізму, технологій такого впровадження на практиці (Makarenko, Słabko, 2015; Druz, Iermakov, Nosko, Shesterova, Novitskaya, 2017).

Цифрові технології у галузі ФКіС та професійній підготовці майбутніх фахівців із ФКіС використовують як засіб навчання й організації інтелектуального дозвілля, для біомеханічного аналізу техніки руху спортсменів, створення моделей тренувальних і змагальних ситуацій і як засіб автоматизації процесів обробки результатів змагань і наукових досліджень, для інформаційно-методичного забезпечення та управління навчально-виховним процесом у ЗВО, спортивних установах і організаціях, при організації моніторингу фізичного стану та здоров'я тих, хто займається, як засіб автоматизації процесів контролю, комп'ютерного тестування фізичного, функціонального, розумового і психологічного станів тих, хто займається, і корекції результатів навчально-тренувальної діяльності.

Значна увага приділяється формуванню практичних навичок роботи з цифровою технікою. Цьому присвячують свої дисертаційні роботи дослідники Л. Карташова (Карташова, 2004), В. Качурівський (Качурівський, 2004), О. Майборода (Майборода, 2002). Автори доводять, що комп'ютерна техніка сприяе індивідуалізації та особистісному спрямуванню навчального процесу, стимулює розвиток навичок самостійної роботи у студентів. На жаль, структура змісту предмета практично не зазнає змін залежно від майбутнього фаху студентів.

Складність цього завдання, на нашу думку, полягає в розробці методично виправданих $\mathrm{i}$ дидактично врівноважених засобів (електронних 
підручників, навчальних програм) навчання для майбутніх фахівців із ФКіС з урахуванням усіх можливостей сучасної техніки.

Мета статті - розглянути результати експерименту щодо підготовки майбутніх фахівців iз ФКіС до упровадження цифрових технологій у професійній діяльності.

Виклад основного матеріалу. Формувальний етап педагогічного експерименту здійснювався протягом 2015-2019 рр. До контрольних груп (КГ) увійшло 106 студентів факультетів фізичного виховання і спорту, яких навчали фахових дисциплін у найбільш поширений спосіб. Експериментальну групу (ЕГ) становили 98 студентів факультетів фізичного виховання і спорту, навчання яких здійснювалося за авторською моделлю. Формування контрольної й експериментальної груп здійснювалося на основі результатів попередніх зрізів таким чином, щоб забезпечити статистичну відповідність рівня підготовленості студентів обох груп. Від усіх учасників була отримана поінформована згода на участь у цьому дослідженні. При цьому досліджувався стан підготовки майбутніх фахівців із ФКіС до впровадження цифрових технологій у професійній діяльності.

Під час експериментальної підготовки майбутніх фахівців із ФКіС до упровадження цифрових технологій у професійній діяльності були доцільно поєднані традиційні методи навчання та інноваційні технології, що передбачають використання інновацій не лише в навчально-виховному процесі, а й для професійного зростання та фізичного вдосконалення; широко використано

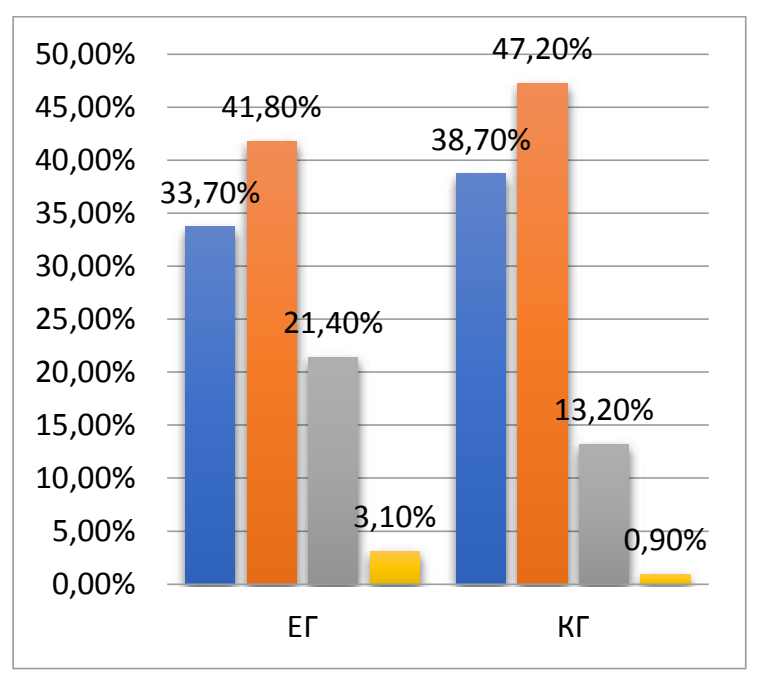

a)

$\square$ низький $\square$ середній новітні форми організації та проведення навчальних занять зі зростанням ролі інтерактивних форм організації навчального процесу, використанням індивідуалізованих освітніх траєкторій для студентів; залучено сучасні технології і засоби контролю; створено комплекси інноваційних гімнастичних вправ та відповідний цифровий супровід.

Під час визначення рівнів готовності майбутнього фахівця із ФКіС до впровадження цифрових технологій у професійній діяльності ми спиралися на такі показники, як обсяг знань (предметний критерій), рівень інформативної підготовленості та виконання організаційних дій (практичний критерій), рівень мотивації та самоаналізу майбутніх фахівців iз ФКіС (психологічний критерій). Розроблена нами класифікація рівнів готовності майбутнього фахівця iз ФКіС до впровадження цифрових технологій у професійній діяльності містить чотири сходинки:

- низький рівень (впровадження цифрових технологій у професійну діяльність відбувається фрагментарно, не має системи),

- середній рівень (вміння здійснювати елементарні дії в галузі цифрових технологій ФКіС за зразком, впровадження їх у професійну діяльність переважно на базі відеоматеріалу),

- достатній рівень (знання основних фактів i понять у галузі цифрових технологій ФКіС, володіння базовими уміннями для виконання професійних завдань),

- високий рівень (перенесення знань у нові ситуації, створення оригінальних підходів, алгоритмів пізнавальних і практичних дій щодо застосування ЦТ).

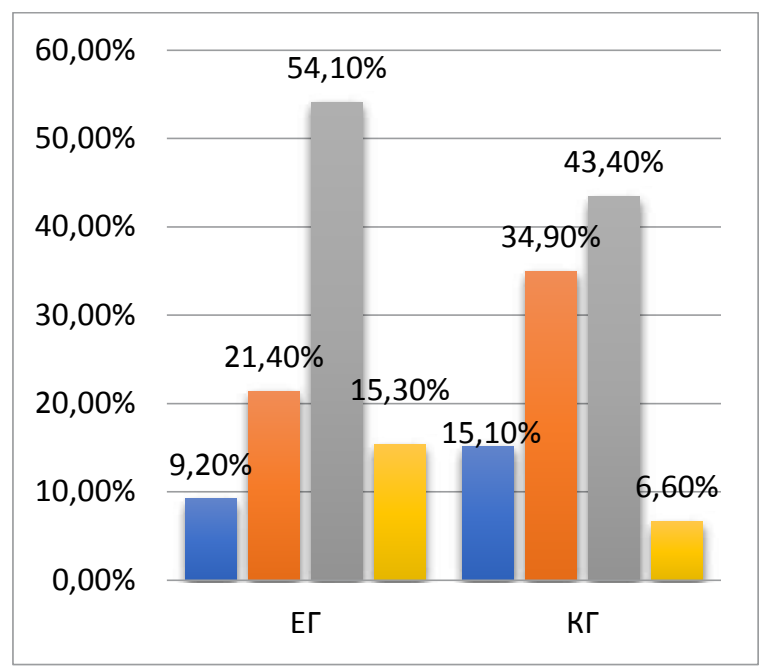

б)

$\square$ достатній $\square$ високий

Рис. 1. Діаграма рівнів для ЕГ та КГ на початку експерименту (а) та після експерименту (б) 
Мазоренко С. Резумьтати експериментальної підготовки майьутніх фахівців ...

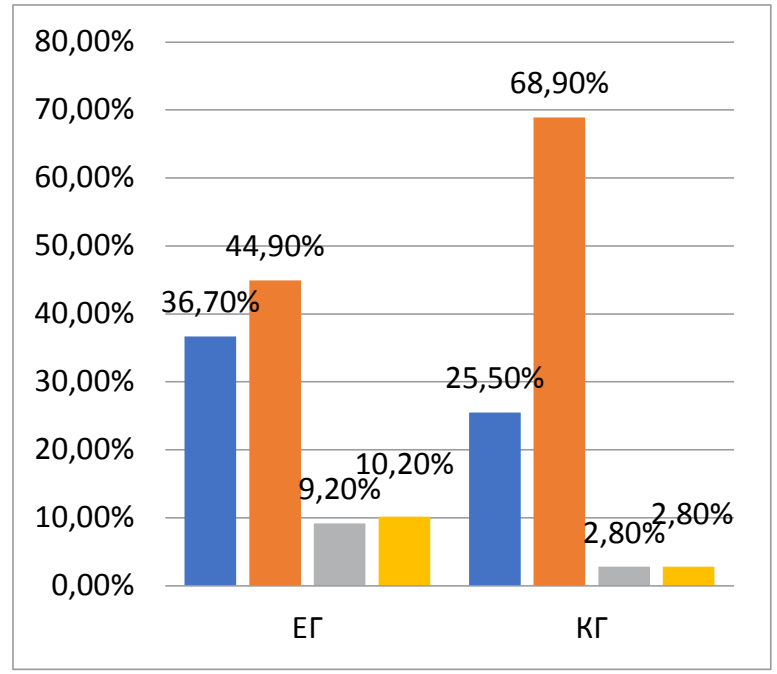

a)

$\square$ низький

$\square$ середній

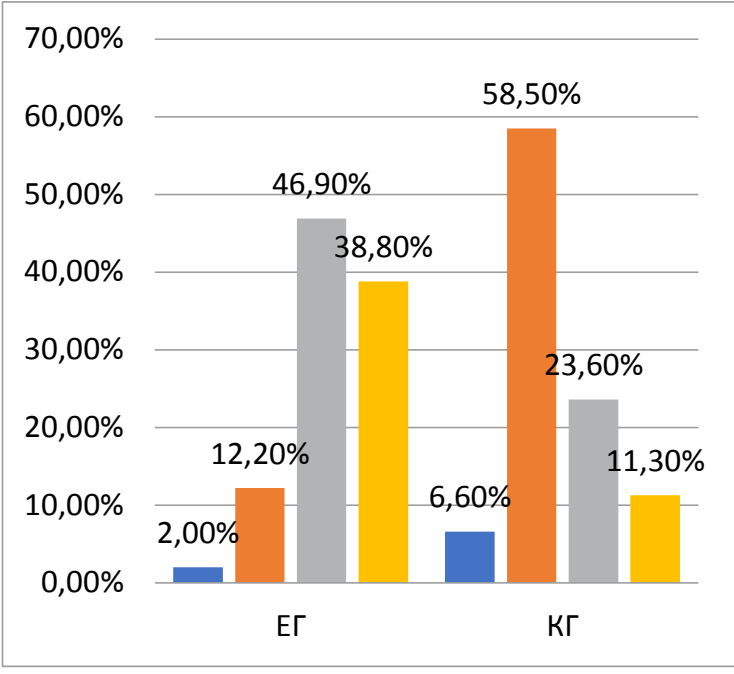

б)

$\square$ достатній $\square$ високий

Рис. 2. Діаграма рівнів для ЕГ та КГ на початку експерименту (а) та після експерименту (б)

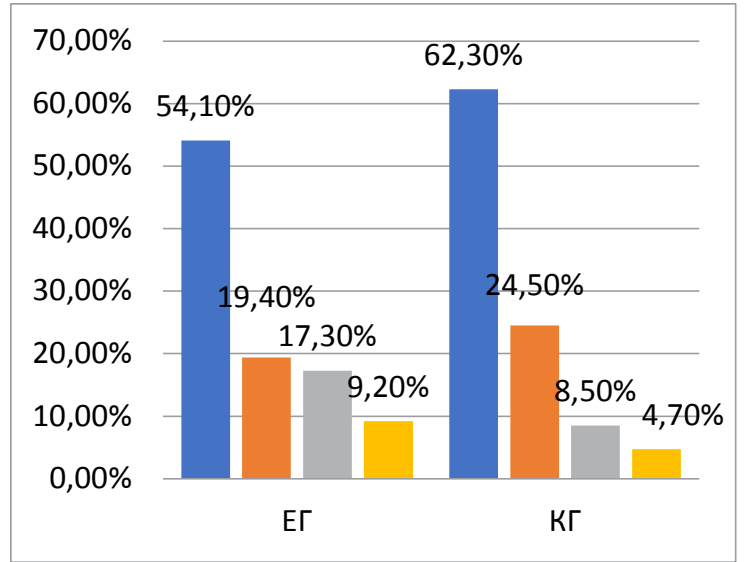

a)

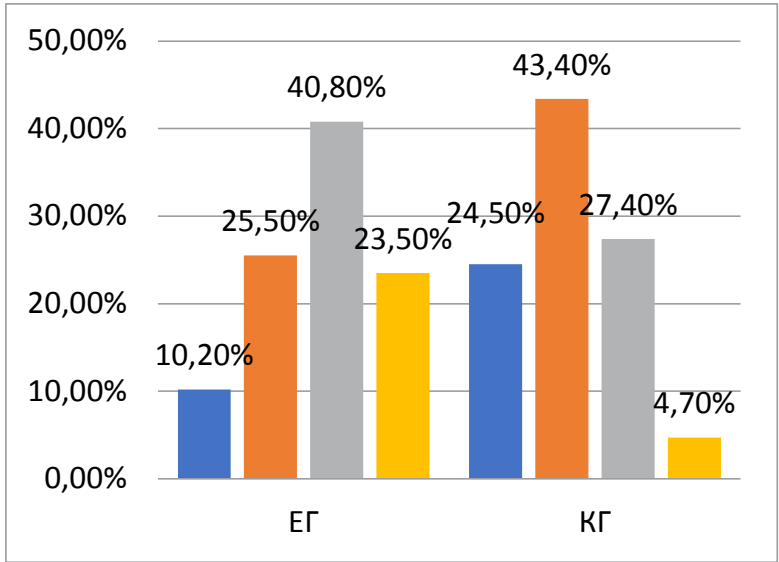

б)

$\square$ достатній $\square$ високий

Рис. 3. Діаграма рівнів для ЕГ та КГ на початку експерименту (а) та після експерименту (б)

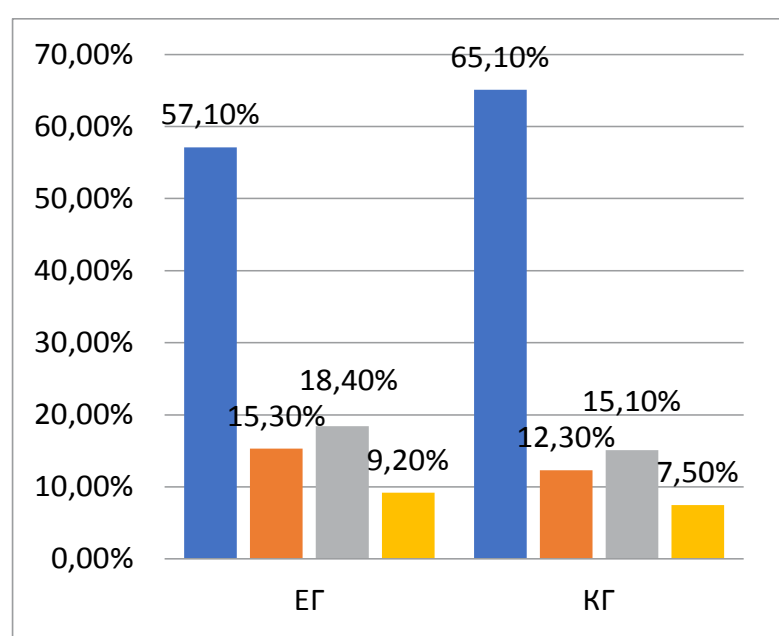

a)

$\square$ низький

$\square$ середній

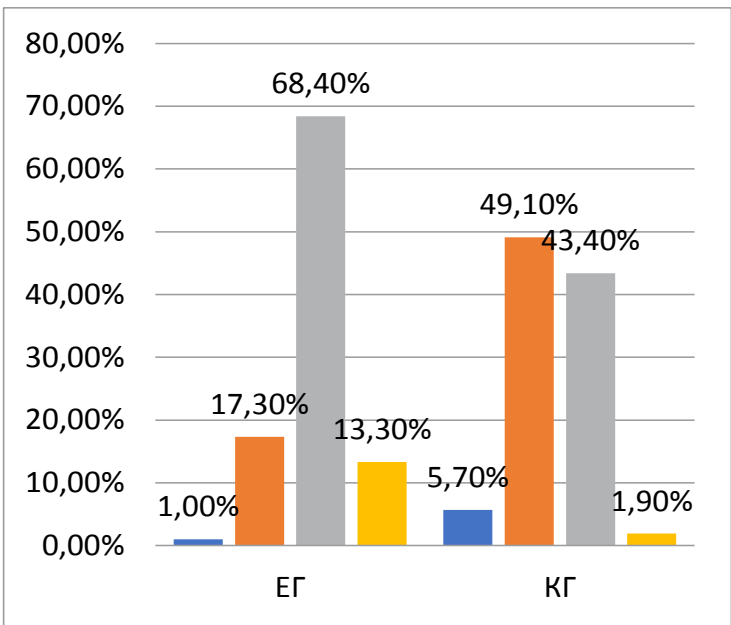

б)

$\square$ достатній $\square$ високий

Рис. 4. Діаграма рівнів для ЕГ та КГ на початку експерименту (а) та після експерименту (б) 
Результати педагогічного експерименту за показником «Обсяг знань (О3)» розподілилися таким чином (рис. 1).

Перевірка на основі критерію Стьюдента для оцінки середніх відбувалася 3 використанням статистичних функцій MS Excel. На початку експерименту на рівні значущості $0,05 T_{\text {крum. }}=1,97 \mathrm{i}$ воно більше за $T_{\text {експ. }}=-1,21$ по модулю. Це означає, що вибірки статистично однаковими входять у педагогічний експеримент. Після проведення експерименту спостерігаємо позитивну динаміку в обох групах. Водночас потрібно перевірити статистично, чи різними $є$ результати оцінки середніх. На рівні значущості $0,05 T_{\text {крит. }}=1,97$ і воно по модулю менше за модуль $T_{\text {експ. }}=-3,23$. Це означає, що на виході з педагогічного експерименту вибірки статистично різні, і це не можна пояснити випадковими причинами. Таким чином, нами підтверджено на рівні значущості 0,05 ефективність підготовки майбутніх фахівців із ФКіС до впровадження цифрових технологій у професійній діяльності за показником «Обсяг знань».

Загальні результати щодо кількісної характеристики «Інформатичної підготовленості» студентів обох груп розподілилися таким чином (рис. 2). За діаграмою (рис. 2) можна припустити, що на початку експерименту вибірки статистично однакові.

Перевіримо це на основі критерію Стьюдента для оцінки середніх із використанням статистичних функцій MS Excel. На початку експерименту на рівні значущості $0,05 T_{\text {крит. }}=1,97 \mathrm{i}$ воно по модулю більше за модуль $T_{\text {ексn. }}=0,65$. Це означає, що вибірки статистично однаковими входять у педагогічний експеримент. Після проведення експериментальної підготовки спостерігаємо позитивну динаміку в обох групах. Водночас потрібно перевірити статистично, чи різними $\epsilon$ результати оцінки середніх. Зафіксуємо рівень значущості 0,05 і побудуємо гіпотези: $H_{0}: \mu_{E \Gamma}=$ $\mu_{K \Gamma}$ (тобто середні однакові), На: $\mu_{E \Gamma} \neq \mu_{K \Gamma}$ (тобто середні статистично різні). На рівні значущості $0,05 T_{\text {крum. }}=1,97$, і воно по модулю менше за модуль $T_{\text {ексn. }}=-10,09$. Це означає, що на виході з педагогічного експерименту вибірки статистично різні, i це не можна пояснити випадковими причинами. Таким чином, нами підтверджено на рівні значущості 0,05 ефективність підготовки майбутніх фахівців із ФКіС до упровадження цифрових технологій у професійній діяльності за показником «Інформативна підготовленість».

Загальні результати щодо кількісної характеристики «Організаційні дії» студентів обох груп розподілилися таким чином (рис. 3 ).

За діаграмою (рис. 3) можна припустити, що на початку експерименту вибірки статистично однакові. Перевіримо це на основі критерію Стьюдента для оцінки середніх із використанням статистичних функцій MS Excel (табл. 8).

На початку експерименту на рівні значущості $0,05 T_{\text {крит. }}=1,97$, і воно по модулю більше за $T_{\text {експ. }}=-1,71$. Це означає, що вибірки статистично однаковими входять у педагогічний експеримент. Після експериментальної підготовки спостерігаємо позитивну динаміку в обох групах. На рівні значущості $0,05 T_{\text {крum. }}=1,97$, і воно по модулю менше за модуль $T_{\text {ексn. }}=-4,76$. Це означає, що на виході $з$ педагогічного експерименту вибірки статистично різні, і це не можна пояснити випадковими причинами. Таким чином, нами підтверджено на рівні значущості 0,05 ефективність підготовки майбутніх фахівців із ФКіС до упровадження цифрових технологій у професійній діяльності за показником «Організаційні дії».

Одним із показників сформованості готовності майбутніх фахівців із ФКіС до впровадження цифрових технологій у професійній діяльності за індивідуально-особистісним критерієм визначено мотивацію. Загальні експериментальні результати розподілилися таким чином (рис. 4).

За діаграмою (рис. 4) можна припустити, що вибірки на початку експерименту статистично однакові. Перевірка на основі критерію Стьюдента для оцінки середніх відбувалася з використанням статистичних функцій MS Excel і показала, що на рівні значущості $0,05 T_{\text {крum. }}=1,97 \mathrm{i}$ воно по модулю більше за модуль $T_{\text {ексn. }}=-0,45$. Це означає, що вибірки статистично однаковими входять у педагогічний експеримент. Після проведення підготовки спостерігаємо позитивну

Таблиця 1

Розподіл учасників за рівнями на початку експерименту

\begin{tabular}{|c|c|c|c|c|c|}
\hline \multicolumn{2}{|c|}{ Рівні } & Низький & Середній & Достатній & Високий \\
\hline \multirow{2}{*}{ ЕГ } & до & $31,6 \%$ & $36,7 \%$ & $21,4 \%$ & $10,2 \%$ \\
\cline { 2 - 6 } & після & $20,4 \%$ & $21,4 \%$ & $35,7 \%$ & $22,4 \%$ \\
\hline \multirow{2}{*}{ КГ } & до & $34,0 \%$ & $38,7 \%$ & $22,6 \%$ & $4,7 \%$ \\
\cline { 2 - 6 } & після & $31,1 \%$ & $32,1 \%$ & $27,4 \%$ & $9,4 \%$ \\
\hline
\end{tabular}


динаміку в обох групах. Статистична перевірка, чи різними $\epsilon$ результати оцінки середніх із застосуванням пакету аналізу табличного процесора MS Excel, показала такі результати: на рівні значущості $0,05 T_{\text {крит. }}=1,97$ і воно по модулю менше за модуль $T_{\text {ексn. }}=-6,22$. Це означає, що на виході 3 педагогічного експерименту вибірки статистично різні, і це не можна пояснити випадковими причинами. Таким чином, нами підтверджено на рівні значущості 0,05 ефективність підготовки майбутніх фахівців із ФКіС до впровадження цифрових технологій у професійній діяльності за показником «Мотивація».

Відповіді студентів контрольної та експериментальної груп на тест для визначення показника «Самоаналіз» розподілилися таким чином (табл. 1).

Перевіряли статистичну подібність та відмінність розподілу частот на основі критерію Стьюдента для різних вибірок із різними дисперсіями, використовуючи відповідні функції табличного процесора MS Excel. За критерієм Стьюдента вибірки на початку експерименту подібні (середні не відрізняються), а тому на рівні значущості 0,05 $\epsilon$ підстави говорити про еквівалентність груп на початку педагогічного експерименту. Позитивна динаміка після експерименту спостерігається в обох групах, але в експериментальній групі більш інтенсивно. За критерієм Стьюдента оцінки середніх бачимо, що в експериментальній групі середній бал вищий на рівні значущості 0,05 . Це означає, що більш значущими виявилися позитивні зміни в експериментальній групі, яка навчалася за експериментальною методикою.

Висновки. Проведення експериментальної підготовки майбутніх фахівців із ФКіС до впровадження цифрових технологій у професійній діяльності вимагало проведення педагогічного експерименту, який передбачав порівняння навчальних досягнень майбутніх фахівців із ФКіС контрольної та експериментальної груп. Це зумовило потребу в розробці критеріальної бази дослідження. Було розроблено, відповідно, три критерії - предметний, практичний і психологічний. Їхніми показниками виступили обсяг знань, інформативна підготовленість, організаційні дії, мотивація, самоаналіз. Педагогічний експеримент показав ефективність запропонованої експериментальної підготовки майбутнього фахівця із ФКіС до впровадження цифрових технологій у професійній діяльності, що підтверджено статистичними методами (методи Стьюдента) на рівні значущості 0,05 .

Перспективними вважаємо дослідження питань запровадження в освітній процес професійної підготовки майбутніх фахівців із ФКіС технологій контекстного навчання, мультимедійного наповнення курсів, організації дистанційного навчання тощо.

\section{СПИСОК ВИКОРИСТАНИХ ДЖЕРЕЛ}

1. Ашанін В. С. Аналіз практичного досвіду формування інформаційної культури студентів Харківської державної академії фізичної культури. Науково-методичні основи використання інформаційних технологій в галузі фізичної культури та спорту. 2017. Вип. 1. С. 7-11.

2. Гуревич Р. С., Коломієць Т. Д. Методичні аспекти використання інформаційно-комунікаційних технологій у навчанні. Вісник ЛНУ ім. Тараса Шевченка. 2010. № 1 (188). С. 60-67.

3. Карташова Л. А. Особистісно орієнтована система навчання основ інформаційних технологій в процесі підготовки майбутніх вчителів іноземних мов : дис. ... канд. пед. наук : 13.00 .02 / Національний педагогічний ун-т ім. М.П. Драгоманова. Київ, 2004. 247 с.

4. Качурівський В. О. Організація самостійної роботи студентів агроколеджів із набуття умінь та навичок практичного застосування комп'ютерної техніки : дис. ... канд. пед. наук : 13.00 .04 / Тернопільський держ. педагогічний ун-т ім. Володимира Гнатюка. Тернопіль, 2003. 235 с.

5. Майборода О. В. Становлення і розвиток комп'ютерної освіти студентів педагогічних коледжів України : дис. ... канд. пед. наук : 13.00.04 / Центральний ін-т післядипломної освіти АПН України. Київ, 2002. 238 с.

6. Сухобок О. Ю. Засоби інноваційних педагогічних технологій у підготовці майбутніх учителів фізичної культури. Педагогіка, психологія та медико-біологічні проблеми фізичного виховання і спорту. 2011. № 12. С. $109-112$.

7. Druz V. A., Iermakov S. S., Nosko M. O., Shesterova L. Y., Novitskaya N. A. The problems of students' physical training individualization. Pedagogics Psychology MedicalBiological Problems of Physical Training and Sports. 2017. № 21 (2). C. 51-59. doi: 10.15561/18189172.2017.0201

8. Makarenko L., Słabko W. Informatization of education in the era of globalization of educational space. Szkoła Zawód-Praca. (2015). T. 10. P. 20-29.

\section{REFERENCES}

1. Ashanin V. S. (2017). Analiz praktychnoho dosvidu formuvannia informatsiinoi kultury studentiv Kharkivskoi derzhavnoi akademii fizychnoi kultury [Analysis of practical experience in the formation of information culture of students of the Kharkiv State Academy of Physical Culture]. Scientific and methodological bases of using information technologies in the field of physical culture and sports, 1, 7-11. (in Ukrainian) 
2. Gurevich R. S., Kolomiets T. D. (2010). Metodychni aspekty vykorystannia informatsiino-komunikatsiinykh tekhnolohii u navchanni [Methodological aspects of the use of information and communication technologies in education]. Bulletin of Taras Shevchenko LNU, 1 (188), 60-67. (in Ukrainian)

3. Kartashova, L. A. (2004). Osobystisno oriientovana systema navchannia osnov informatsiinykh tekhnolohii v protsesi pidhotovky maibutnikh vchyteliv inozemnykh mov [Personally oriented system of teaching the basics of information technology in the process of training future foreign language teachers]. (Unpublished doctoral dissertation). Kyiv. (in Ukrainian)

4. Kachurivskyi, V. O. (2003). Orhanizatsiia samostiinoi roboty studentiv ahrokoledzhiv iz nabuttia umin ta navychok praktychnoho zastosuvannia kompiuternoi tekhniky [Organization of independent work of students of agricultural colleges on acquisition of abilities and skills of practical application of computer equipment]. (Unpublished doctoral dissertation). Ternopil. (in Ukrainian)

5. Maiboroda, O. V. (2002). Stanovlennia i rozvytok kompiuternoi osvity studentiv pedahohichnykh koledzhiv Ukrainy [Formation and development of computer education of students of pedagogical colleges of Ukraine]. (Unpublished doctoral dissertation). Kyiv. (in Ukrainian)

6. Sukhobok O. Y. (2011). Zasoby innovatsiinykh pedahohichnykh tekhnolohii u pidhotovtsi maibutnikh uchyteliv fizychnoi kultury [Means of innovative pedagogical technologies in the training of future teachers of physical culture]. Pedagogy, psychology and medical-biological problems of physical education and sports, 12, 109-112.

7. Druz V. A., Iermakov S. S., Nosko M. O., Shesterova L. Y., Novitskaya N. A. The problems of students' physical training individualization. Pedagogics Psychology Medical-Biological Problems of Physical Training and Sports. 2017. № 21 (2). C. 51-59. doi: 10.15561/18189172.2017.0201

8. Makarenko L., Słabko W. Informatization of education in the era of globalization of educational space. Szkoła Zawód-Praca. 2015. T. 10. P. 20-29. 